http://dx.doi.org/10.12775/szhf.2020.021

\author{
Robert GrZyWACZ, SJ \\ Jesuit University Ignatianum in Krakow, Poland \\ E-MAIL: ROBERT.GRZYWACZ@IGNATIANUM.EDU.PL \\ ORCID: 0000-0001-8353-6238
}

\title{
Ricourian Philosophy of Life and the Question of the Fundamental - a Final Concession in Favour of Immediacy?
}

\section{Introductory Remarks}

In recent years, a somewhat significant number of researchers in the thought of Paul Ricœur have devoted their studies to the problem of life in his works. ${ }^{1}$ It is striking that, similarly but rather independently, some contributions of value have appeared in the last decade that deal with the notion of the Fundamental (Essential), especially within the frame of Ricœurian philosophy of religion. ${ }^{2}$ Although one may discern some traces of the

1 See for example, Paul Ricour et Michel Henry: Entre héritages et destinées phénoménologiques, eds. Jean-Sébastien Hardy, Jean Leclercq, Cyndie Sautereau (Louvain-la-Neuve: Presses Universitaires de Louvain, 2016); A Companion to Ricour's "Freedom and Nature", ed. Scott Davidson (Lanham, MD: Lexington Books, 2018).

2 See for example, A Passion for the Possible: Thinking with Paul Ricour, eds. Brian Treanor, Henry Isaac Venema (New York: Fordham University Press, 2010); Études Ricouriennes 
acknowledgment of the connexion between both problems, ${ }^{3}$ they are usually treated separately. In my investigation below, I attempt to challenge this dominant tendency. What seems to be ultimately at stake in such an endeavour is the question of the limits of the hermeneutical approach and, by the same token, that of the coherency of the entire philosophical project of the French philosopher. To put the issue more explicitly, one could ask if in his way of dealing with both topics, namely life and the Fundamental, the referred author does not relinquish his usual hermeneutic rigor and subsequently accedes to the very kind of immediacy of which he was always wary. ${ }^{4}$

To answer this question, as well as to attain a larger goal of my research of establishing or denying the theoretical (hermeneutical) consistency of Ricœur's work up to its final stage, I will proceed by taking the following steps. First, I try to concisely demonstrate the pertinence of the subject and make a brief account of a few selected but representative pieces of research in the matter in order to precise the present state of the question. Second, having chosen Henry as a critical reader of Ricœur's philosophy of life (more exactly, in its version focused on the unconscious) - the more relevant the critic, the more deeply concerned they are with the problem of immediacy I recall the crucial points and arguments in the debate. Third, while retaining the core of the objections Henry addresses to the author of Freud and Philoso$p h y$, I transfer it to the field of reflexion about the role that the concept of life plays in the late writings of the hermeneutical thinker, especially with regard

/ Ricour Studies 3, 2 (2012); Marianne Moyaert, In Response to the Religious Other: Ricour and the Fragility of Interreligious Encounters (Lanham: Lexington Books, 2014); Brian Gregor, Ricœur's Hermeneutics of Religion: Rebirth of the Capable Self (Lanham: Lexington Books, 2019).

3 In an important study on the phenomenology of life in Henry and Ricœur, S. Davidson notes that there are two decisive stages in Ricœurian elaboration of the matter: in his doctoral thesis and in the late writings published as a posthumous volume Living up to death (Fr. 2007; Eng. 2009) - Scott Davidson, "La phénoménologie de la vie: entre Henry et Ricœur", transl. Daniel Gillis, in: Paul Ricœur et Michel Henry. Entre héritages et destinées phénoménologiques, eds. Jean-Sébastien Hardy, Jean Leclercq, Cyndie Sautereau (Louvain-la-Neuve: Presses Universitaires de Louvain, 2016), 34. Besides, this view meets that of the author himself - Paul Ricœur, Critique and conviction: conversations with François Azouvi and Marc de Launay, transl. Kathleen Blamey (New York: Columbia University Press, 1998), 157.

4 See Ricœur, Critique and conviction, 139; Paul Ricœur, Living up to death, transl. David Pellauer (Chicago: The University of Chicago Press, 2009), 16. 
to the Fundamental. Finally, I attempt to possibly account for the controversy defined above, i.e. mediation vs immediacy, and I propose a particular reading of the reproach that was uttered by Henry, namely the reading that takes up some early phenomenological achievements of Ricœur.

Actually, the problem of life does not seem to be evidently an important one as far as one would consider the heritage of the author of Oneself as Another in its integrity. Let the confession of the philosopher himself (in 1995) suffice: "I am right now reflecting on the theme of life, which I had always fled; following the early Husserl, I am very suspicious of Lebensphilosophie, of the idea of a philosophy of life". ${ }^{5}$ And, just after his interlocutor recalls his early contribution to the matter in Freedom and Nature, he adds that it was the case but "under the heading of the absolute involuntary", while "[t]he level of life, as human life, is also that of desire [...] this is also the level on which memory is constituted, beneath discourses, before the stage of predication". ${ }^{6}$ With the preceding predication, and thus anterior to any linguistic differentiation, one reaches exactly the point where the notion of something fundamental, in the Ricœurian sense to be defined, may appear. This is why a new elaboration of the question of life only returns in confrontation with death when, what is more, one is faced with a kind of experience; an experience connected to the event that the author did not want to be crushed by beforehand. ${ }^{7}$ As to such a reorientation of his project, he speaks in even more existential terms, of "the opposite journey" to make with regard to "the journey [...] made during these decades of life towards texts and discourses". The opposite one leads "from books to life". ${ }^{9}$ What is the meaning of this reorientation for the entire work? Is it only a momentary accent or an inherently decisive step that sheds some light on the examined thought as a whole? In what follows, I argue on behalf of the second view. Moreover, I hold the essential point of the

5 Ricœur, Critique and conviction, 93.

${ }^{6}$ Ibidem, 93-94. It is noteworthy that the concept of life throughout the relevant Ricœurian writings does not manifest the unitary traits, what, after all, the last quotation helps to guess. Nor do we claim such a homogeneity to be the case in our investigation below, although the methodological significance of the concept remains at stake.

7 Ibidem, 145, 157, 93.

8 François Dosse, Paul Ricour. Les sens d’une vie (1913-2005) (Paris: La Découverte, 2008), 681 (my translation).

9 Ibidem (tr. RG). 
critique addressed to Ricœur to be valid, even if this statement requires more strict clarifications as to its extent and limits.

\section{Ricœur's Philosophy of Life: The Present State of the Question}

In my brief overview of some of the selected and relatively recent commentaries on the investigated theme, I focus principally on two of the aforementioned books: Paul Ricour et Michel Henry. Entre héritages et destinées phénoménologiques (2016) and A Companion to Ricour's Freedom and Nature (2018). Starting from the introduction of the first one, its authors, namely Hardy and Leclercq, highlight the very roots of the circular "long way" of selfunderstanding by self-interpretation in Ricœur. They can be identified with the tension between the irreducible and inexhaustible anteriority of life, on the one hand, and a self-ignorance or even a kind of self-alienation on the other. ${ }^{10}$ The persistence of such a tension makes reasonable the expectation that approaches that at first glance seem to be contradictory (immediate vs mediated) may in fact act as a relay with reference to different aspects of the matter. ${ }^{11}$ In my presentation below, I adopt this hypothesis of the authors. Furthermore, they draw the reader's attention to some of the more indirect occurrences of allusions to the concept of life in Ricœur, in between both temporal extremities of the thinker's intellectual trajectory (when the issue is treated more explicitly), as for example in cases of the "prenarrative"12 or the "untellable". ${ }^{13}$ In addition, the notion of existence which underlines

${ }^{10}$ Jean-Sébastien Hardy, Jean Leclercq, "Introduction: Paul Ricour et Michel Henry, entre héritages et destinées", in: Paul Ricour et Michel Henry. Entre héritages et destinées phénoménologiques, eds. Jean-Sébastien Hardy, Jean Leclercq, Cyndie Sautereau (Louvain-la-Neuve: Presses Universitaires de Louvain, 2016), 5.

11 Ibidem, 14.

12 Paul Ricœur, Time and Narrative, vol. 1, transl. Kathleen McLaughlin, David Pellauer (Chicago: The University of Chicago Press, 1984), 74.

13 Paul Ricour, Oneself as Another, transl. Kathleen Blamey (Chicago: The University of Chicago Press, 1992), 320. 
"the unsurpassable character [or nature] of life"14 as well as an implicit ontology of the acting and suffering individual ${ }^{15}$ indicate to the same vital background. This background, however, turns out to be unreachable unless hermeneutically. ${ }^{16}$ In the view of Hardy and Leclercq, such a claim echoes a Hegelian interpretation of the operation of reduction by Ricœur, namely the critique of any immediate knowledge, which prevails, for the author of Freud and Philosophy, over Husserl's account of reduction. ${ }^{17}$

On the contrary, according to Serban, it is the reading of the Husserlian work itself that seems to be decisive for the manner in which Ricœur perceives the dimension of life. This singular perspective is the semantic, which implies that life becomes what can be reflected on only inasmuch as it conveys an inchoate meaning and is thus susceptible to some representation. ${ }^{18}$ Actually, the inseparability of life from its representations constitutes the pivotal point that results in the equation of consciousness and representation and this makes the position of hermeneutics an implicit object of the debate. ${ }^{19}$ The consequences of such a view at the same time influence the way of thinking of action and of feeling, which both manifest respective intentionality, i.e. the orientation towards a meaning. ${ }^{20}$ Thus, phenomenology can be defined as an approach that "begins when $[\ldots]$ we interrupt lived experience

14 Paul Ricœur, Freud and Philosophy: An Essay on Interpretation, transl. Denis Savage (New Haven and London: Yale University Press, 1970), 457-458.

15 Ricœur, Oneself as Another, 315-317: "another connection between the phenomenology of the acting and suffering self and the actual and potential ground against which selfhood stands out $[\ldots]$ is Spinoza's conatus [... that binds together] the internal dynamism worthy of the name of life and the power of the intelligence, which governs the passage from inadequate to adequate ideas [...] It is precisely the priority of the conatus in relation to consciousness $[\ldots]$ that imposes on adequate self-consciousness this very long detour".

16 Ricœur, Freud and Philosophy, 458: "The dependence of the Cogito on the positing of desire is not directly grasped in immediate experience, but interpreted by another consciousness [...] The rootedness of reflection in life is itself understood in reflective consciousness only in the form of a hermeneutic truth".

17 Hardy, Leclercq, "Introduction: Paul Ricœur et Michel Henry", 13.

18 Claudia Serban, "De l'hylétique à l'herméneutique: Henry et Ricœur face à Husserl", in: Paul Ricour et Michel Henry. Entre héritages et destinées phénoménologiques, eds. Jean-Sébastien Hardy, Jean Leclercq, Cyndie Sautereau (Louvain-la-Neuve: Presses Universitaires de Louvain, 2016), 17-32.

19 Ibidem, 21-24.

20 Ibidem, 22-28. 
in order to signify it", ${ }^{21}$ and that "renders thematic what was only operative, and thereby makes meaning appear as meaning". 22 As such, its Ricœurian version may be understood as a refusal of the self-sufficiency of its hyletic (material) interpretation, in which life can do without any necessary mediation of signs since these are ultimately secondary. From the Ricœurian point of view, the interpretation of phenomenology in which one overestimates its hyletic (material) dimension risks being reduced to silence. ${ }^{23}$ Yet, simultaneously, any access to immediacy in this way seems to be irreversibly lost.

A number of contributions which follow develop various aspects that have already been mentioned more meticulously. Two of them directly address the problem of the relation between life and its representations. Castonguay tries to shed light on the epistemological presuppositions of Ricœur's hermeneutical appropriation of Freud by means of Henry's reading of the genealogy of psychoanalysis. ${ }^{24}$ The presuppositions that are sought concern the primacy of intentionality in acting with respect to thematic intentionality, which means the possibility of the presence of something potentially meaningful while not yet understood. ${ }^{25}$ This is how desire becomes a model of the meaning which exists, without being taken into consideration. Nevertheless, such a possibility still remains open, justifying psychoanalytical theory as well as its practice. This is why the Ricœurian project never leaves the frame of the

21 Paul Ricœur, Hermeneutics and the Human Sciences: Essays on Language, Action and Interpretation, transl. John Brookshire Thompson (New York: Cambridge University Press, 2016), 76.

22 Ibidem, 77.

23 Paul Ricœur, Time and Narrative, vol. 3, transl. Kathleen Blamey, David Pellauer (Chicago: The University of Chicago Press, 1990), 24: "If this hyletics [of internal time-consciousness] is not to be condemned to silence, among phenomenological data must be counted [... the apprehensions that allow] discourse about the hyletic [... and that] have to borrow from the determinations of objective time". "[...] if the discourse on the hyletic is not to be reduced to silence, the support of something perceived is necessary" (p. 26). It is worthy to note that Serban's account I have summarised above draws from the substantial paper of Bruce Bégout, "L’héritier hérétique. Ricœur et la phénoménologie", Esprit 323, 3-4 (2006): 195-209.

24 Simon Castonguay, "La Généalogie de la psychanalyse de Michel Henry: Des limites du paradigme de la représentation", in: Paul Ricour et Michel Henry. Entre héritages et destinées phénoménologiques, eds. Jean-Sébastien Hardy, Jean Leclercq, Cyndie Sautereau (Louvain-laNeuve: Presses Universitaires de Louvain, 2016), 134.

25 Ibidem, 145. 
so-called metaphysics of representation. ${ }^{26}$ What is truly at stake in this point focuses on the question of whether the pure immanence of life is a sphere exempt of meaning. ${ }^{27}$ The second contribution which challenges the paradigm of representation, from Formisano, is devoted in particular to the practical dimension of life. ${ }^{28}$ The text convincingly demonstrates that if one admits the ontological thesis of the irreducible heterogeneity of reality and its representation, the thesis which characterises material phenomenology, it is difficult to succeed in proposing a theory (sic!) of any concrete practice. In this case, the project of a phenomenological description of life is admittedly valid inasmuch as a foundational endeavour, but its significance becomes problematic when translated to the sphere of actual action.

There are also chapters which examine the potentiality of speaking about life. One of them, by Del Mastro, establishes that taking into account some contemporary attempts to transgress the realm of meaning for the benefit of paying attention to what has the essence of event, the interpretation of the meaning of life could be replaced by a sort of "hermeneutics of life".29 By doing so, on the one hand, one preserves the irreducibility of life to its representations, and on the other, the discourse employed in such cases turns to be affective and performative in nature: it simply realises life's affects and drives without reflecting them in the strict sense. This effectuation of the language of force and affects has properly to do with what founds the dimension of meaning but does not belong to it, namely a kind of "beyond-sense" of pure and autonomous life. This reference to various conceptions of hermeneutics and different views on language (representing vs expressing one) helps us to reformulate our introductory problem of the opposition between immediacy and mediation. If life and representation belong respectively to two incom-

26 Ibidem, 146-147.

27 Ibidem, 149.

28 Roberto Formisano, "Vie et représentation: Henry et Ricœur sur le problème de la praxis", in: Paul Ricœur et Michel Henry. Entre héritages et destinées phénoménologiques, eds. Jean-Sébastien Hardy, Jean Leclercq, Cyndie Sautereau (Louvain-la-Neuve: Presses Universitaires de Louvain, 2016), 195-205.

29 Cesare Del Mastro, "De la co-référence à la co-impression: La phénoménologie henryenne du langage au prisme de Temps et récit", in: Paul Ricœur et Michel Henry. Entre héritages et destinées phénoménologiques, eds. Jean-Sébastien Hardy, Jean Leclercq, Cyndie Sautereau (Louvain-la-Neuve: Presses Universitaires de Louvain, 2016), 95-96. 
mensurable ontological categories, what could guarantee, in the sense which overpasses any accidental coincidence, a compatibility and communicability between them? Such seems to be the case of the aforementioned performative language of life. Are we then really condemned to the alternative: either silent experience or discourse irrevocably separated from the experiential aspect of life? This is precisely what requires further investigation.

The most complete account of Ricœurian philosophy of life may probably be found in two studies by Davidson. ${ }^{30}$ On the one hand, the author stresses that Ricour's phenomenological approach to life develops from Freedom and Nature to Living up to death, given that both mark out two decisive stages of its elaboration. ${ }^{31}$ On the other hand, Davidson's interest privileges only the first stage. The scope of analysis having been thus defined, life appears as a fundamental involuntary situation rooted in human body, the latter being understood in this case in terms of biological organism. As such, it differs from the lived experience which in turn is referred to human living flesh, to recall the famous Husserlian distinction between Körper and Leib. It is precisely in the incapacity of unifying these two different characteristics of life that the core of any philosophical meaning of suffering lies. ${ }^{32}$ This also makes of life "a resolved problem" (a necessity that one has to undergo because the organic functions are independent from will) as well as "a task"33 (a necessity that one may consent to, and thereby shapes the meaning of what remains involuntary). ${ }^{34}$ Yet, the central point in Davidson's presentation of the Ricœurian phenomenology of life may probably be identified with the limitations it sets up with respect to the application of eidetic approach. ${ }^{35}$ It means that the ambiguity of life, which results from its double trait of solution and task, cannot be overcome: it irrevocably unifies the order of limits and that of sources (of creation or renewal). It follows that even this early reflection on

30 Davidson, "La phénoménologie de la vie", 33-48; Scott Davidson, "The Phenomenon of Life and Its Pathos", in: A Companion to Ricour's "Freedom and Nature", ed. Scott Davidson (Lanham, MD: Lexington Books, 2018), 157-172.

31 Davidson, "La phénoménologie de la vie", 34.

32 Ibidem, 41-48.

33 Paul Ricœur, Freedom and Nature: The Voluntary and the Involuntary, transl. Erazim V. Kohák (Evanston: Northwestern University Press, 1966), 417-419.

34 Davidson, "The Phenomenon of Life and Its Pathos", 166.

35 Ibidem, 169-171. 
life in Ricœur's work manifests an openness to its hermeneutical and poetic developments.

\section{Life as Desire: Force and Meaning Versus Force and Affect}

As is perhaps well known, the problem of life is considered within the frame of what one admits to be the absolute involuntary, the lived necessity, alongside character and the unconscious already in Freedom and Nature. Even in the description of the unconscious, one can read as follows: "On the level of affective and memorial matter of consciousness, repression appears to be an aspect of these functions of structure and regulation which govern life itself below the level of consciousness. [...] Living affects consciousness; it is the living myself given to my self. Censorship is a psychic level of the structure at whose mercy I am placed by this life which I have not chosen. Hierarchic, selective, and repressive, the structure introduces a new aspect into the absolute involuntary: the purposiveness of life itself" ${ }^{36}$ As far as these eidetic achievements regarding life are concerned, let us limit ourselves to some more general remarks that will be useful for what follows. Defined as a basic necessity - necessity to exist - which entirely penetrates any living being, life constitutes a value apart since it concretises the indispensable condition of all other values. As with affectivity, it turns out to be unintentional, unobservable. Therefore, the consciousness of life is equated with self-consciousness. Effectively, it takes the form of the apperception of oneself as a body: "the nonperceptive consciousness of my body or [...] the experienced rather than perceived presence of my body to my consciousness. It means that consciousness of life is not consciousness of an object but of my self" ${ }^{37}$ Thus, the author

36 Ricœur, Freedom and Nature, 399. Subsequently, Ricœur undertakes the question of life itself, which is investigated from a triple viewpoint: that of organisation, that of growth, and that of genesis - ibidem, 409-443. Nonetheless, I abandon a more detailed analysis in this direction for two reasons: 1) this part of Ricœurian philosophy of life has already been abundantly commented upon, to quote e.g. S. Davidson; 2) the immediacy vs mediation controversy is absent at this stage of Ricœur's research.

37 Ibidem, 412. 
also stresses the indivisibility of life. By contrast, by means of certain corresponding metaphors, like the spatial one (being in fife), or that of support (being carried by life), the aforementioned ambiguity of life seems to be once more highlighted. Its meaning, that evokes a gracious but revocable gift, or belonging to life as a quality of the universe, and its reference to a foundation coincide intrinsically. ${ }^{38}$

Two of Davidson's observations are of capital importance for our purpose. First, Ricœur's early account of the absolute involuntary principally presupposes the distinction between experience that is pre-reflective in nature and intentionality coupled with reflection. The former term of this distinction corresponds with each of the three figures of the absolute necessity (involuntary): character, the unconscious, and life. Being understood in this way, necessity constitutes a kind of hyletic data, or in other words, impressional pre-given material, which works as a foundational factor without determining causally intentional consciousness. In this sense, life allows for its identification with this material data. ${ }^{39}$ Such a position refers us directly to the debate on the nature of desire. Second, in view of Davidson, the conception of the unconscious that may be found in Freedom and Nature displays incontestable similarities with the sort of reading of Freud's legacy that distinguishes material phenomenology. ${ }^{40}$ This is why the relevant fragments of Ricœur's book Freud and Philosophy seems to constitute the best field to continue our investigation, and what is more, Henry naturally becomes an essential critical reference.

In his comments on this substantial debate of the French philosopher with the founder of psychoanalysis, Miguel Proença challenges Ricœur's fidelity to the presuppositions of the paradigm of representation, where fidelity comes to light in his semantic and hermeneutic approach to desire. ${ }^{41}$ The problem that should be seriously taken into consideration could be recapitu-

38 Ibidem, 413-414.

39 Davidson, "The Phenomenon of Life and Its Pathos", 163.

40 Ibidem, 171, n. 3.

${ }^{41}$ Nuno Miguel Proença, "La signification de l'inconscient: Psychanalyse, herméneutique et phénoménologie de la vie", in: Paul Ricour et Michel Henry. Entre héritages et destinées phénoménologiques, eds. Jean-Sébastien Hardy, Jean Leclercq, Cyndie Sautereau (Louvain-laNeuve: Presses Universitaires de Louvain, 2016), 112-121. 
lated in the following doubt: if the unconscious is to be phenomenologically described in terms of a "primacy of the unreflected over the reflected, of the operative over the uttered, of the actual over the thematic", ${ }^{42}$ or even in terms of the priority of passive genesis with regard to active one, it has rather more to do with the psychoanalytical preconscious than with the unconscious. It is the case since "the analytic unconscious [...] is not a receptacle of contents but a center of intentions, of orientations-toward, of meaning". ${ }^{43}$ Hence the meaning at stake turns out to be what is incorporated in any significant behaviour. In other words, it is these expressions of the unconscious itself, as a working energy, which are to be interpreted. Moreover, what additionally comes into play in psychoanalysis is the existence of a barrier that separates meaning from its becoming conscious and that is expressed by the notion of repression. Therefore, it seems that phenomenological model does not sufficiently take into account the difference of the meaning to be interpreted in drives' sphere, when compared to its representational counterparts: "repression is a real exclusion which a phenomenology of the implicit or cointended can never reach". ${ }^{44}$

Let us recall that Ricœur tries to cope with the enumerated difficulties following the order in which he has previously demonstrated some closeness of phenomenology and psychoanalysis, namely: 1) reduction as the phenomenological attitude par excellence; 2 ) intentionality as the main phenomenological theme; 3) the question of language and meaning as regards desire; and 4) the problem of intersubjective structure of desire. ${ }^{45}$ For our purpose, I focus solely on the third point. Undoubtedly, repression does not constitute the only challenge that the right technique which is required has to face in order to correctly establish the meaning incorporated in behavioural structures. The intrusion of the economic point of view and of energetic involvement (charge, cathexis) that both remain untranslatable into phenomenological conceptualisation entails further consequences. Examples abound: "Conflicts, formations of compromise, facts of distortion - none of these can be stated in a reference system restricted to relations of meaning to meaning,

\footnotetext{
42 Ricœur, Freud and Philosophy, 379.

43 Ibidem, 392.

44 Ibidem.

45 Ibidem, 376-390.
} 
much less, [...] of literal meaning to intended meaning" ${ }^{46}$ For this reason, what phenomenology helps us to grasp are "the relations of meaning between the instinctual representatives and their derivatives", while "the remoteness and distortion that separate those derivatives from their roots, and the division into two types of derivatives, the ideational and the affective, require an instrument of investigation that phenomenology cannot provide". ${ }^{47}$ Particular difficulties result from the use of the idea of transforming energy into meaning. All these complications highlight the need for an "energy discourse" which would be able to combine desire and language, the natural (economic) and the signifying (intentional). ${ }^{48}$ What becomes relevant in this context is the Ricœurian interpretation of Lacan's famous thesis about quasi-linguistic way in which the unconscious is structured. According to the author of Freud and Philosophy, such a quasi-linguistic interpretation of the unconscious does not intend to replace the economic one, but to parallel (to double) the latter in the domain of meaning without reducing it to the former. It is fundamentally possible inasmuch as "there is no economic process to which there cannot be found a corresponding linguistic aspect". ${ }^{49}$ Thereby, a kind of analogy between the unconscious on the one hand, and ordinary language on the other, may emerge. This entails that, while differing from linguistic phenomenon in the strict sense, the mechanisms of the unconscious are susceptible to an interpretation in terms of the "paralinguistic distortions of ordinary language". ${ }^{50}$ The distortions in question consist of the confusion or blending of two dimensions: infralinguistic (pictorial representation) and supralinguistic (mythical representation). Hence the importance of the comparative term "like": the unconscious is structured like a language. This utterance ultimately points out to "the correlation between hermeneutics and energetics" ${ }^{51}$

What results from the above attainments for the grasp of life as desire? First, there is a substantial critique of immediacy: "immediate consciousness

\footnotetext{
46 Ibidem, 394.

47 Ibidem, 393.

48 Ibidem, 395.

49 Ibidem, 403.

50 Ibidem, 404.

51 Ibidem, 408.
} 
finds itself dispossessed to the advantage of another agency of meaning - the transcendence of speech or the emergence of desire. This dispossession [...] is to be achieved as a kind of ascesis of reflection", ${ }^{52}$ which may even be called "an antiphenomenology, an epochê in reverse". ${ }^{53}$ The intentional phenomenology fails in its attempts to cope with the operative unconscious. Second, a crucial question that arises at this stage may be formulated as follows: "how the dynamics expressed in the notions of discharge, repression, cathexis relates to a semantics of desire?" 54 Ricœur admits that the realism of the unconscious may be understood as a sort of combination of empirical realism with transcendental idealism, like in Kant. ${ }^{55}$ This requires that its reality turns out to be accessible merely by means of a representation that in turn combines the living desire and intentionality in itself. On the one part, since the realism in question is "a realism of the instinctual representatives, and not of the instincts themselves [...] it is also a realism of the knowable and not of the unknowable, the ineffable, the unfathomable". ${ }^{56}$ On the other hand, it remains indispensable to recognise "the nonautonomy of knowledge, its rootedness in existence, the latter being understood as desire and effort", which results from "the unsurpassable nature of life" ${ }^{57}$ In this context, Ricœur admittedly also acknowledges that he connects his own early reflections regarding life with those of Freud by way of this discussion. Yet one important difference remains decisive: the "dependence of the Cogito on the positing of desire" having been admitted, the thinker stresses that it "is not directly grasped in immediate experience [...] It is not at all a felt or perceived dependence, but rather a deciphered dependence". 58

Naturally, such a reading does not constitute the only possibility and a different one may be found in Henry's The Genealogy of Psychoanalysis. ${ }^{59}$

52 Ibidem, 422.

53 Ibidem, 424.

54 Proença, "La signification de l'inconscient", 124 - compare with Ricœur, Freud and Philosophy, 6.

55 Ricœur, Freud and Philosophy, 432-439.

56 Ibidem, 435.

57 Ibidem, 458.

58 Ibidem.

59 Michel Henry, The Genealogy of Psychoanalysis, transl. Douglas Brick (Stanford, California: Stanford University Press, 1993). 
What distinguishes this other interpretation is the efficacy of affect with respect to representation, which is produced or repressed due to the former. In other words, desire in the quest of meaning is replaced by affectivity that denotes the identification of drive and affect. ${ }^{60}$ This identification becomes effective through "the incessant coming of each representative content into the condition that is its own, so that the coming itself, as pro-duction, always hides itself and disappears in its product". ${ }^{11}$ If there is a meaning within such a process, it can merely be "the movement of that pure self-experiencing, that pure affection [...] reduced to its affectivity, independent of the light of the world [...] a completely different concept of meaning". ${ }^{62}$ Instead of "something expressible, offered to a hermeneutical reading [...] opens the domain in which there is no intentionality or meaning", ${ }^{63}$ to be concise, an "unconscious activity". ${ }^{4}$ Hence, a meaningless life and its self-affective and self-sufficient functioning that render memory, representation, and utterance possible, form the foundation of an ethical renewal and thus work therapeutically. ${ }^{65}$ From such a point of view, a Ricœurian account that combines energetics and hermeneutics, turns to be superficial. It eludes the central problem that the division into physical reality and representative consciousness and misses something essential: feeling, affect, in a word: an Archi-Body that subsist at the intersection of the physical and the mental. ${ }^{66}$

In such a theoretical context, the author of The Genealogy of Psychoanalysis addresses some significant critical remarks to Ricœur's reading of Freud

60 Proença, "La signification de l'inconscient", 126-128.

61 Henry, The Genealogy of Psychoanalysis, 291.

62 Ibidem, 294.

63 Ibidem, 296.

${ }^{64}$ Ibidem, 297.

65 Proença, "La signification de l'inconscient", 129-130. Let us recall that such an interpretation rejoins the reading of Ricœur's early phenomenology of life by Davidson, where, the limits of eidetic view having been set by means of the analysis of consent, some appreciation of the creative dimension of life could appear - Davidson, "The Phenomenon of Life and Its Pathos", 170-171.

${ }^{66}$ See Henry, The Genealogy of Psychoanalysis, 300-303, 325. For Henry, neuronal approach manifests an attempt to inscribe "in the organism [...] a double ontological receptivity: transcendental receptivity in regard to the world [...] and transcendental receptivity in regard to self" - ibidem, 306. 
which may be understood as a critique of the Ricœurian grasp of life. ${ }^{67}$ However, what really counts for us is not this direct address of Henry's to the hermeneutical philosopher, but a few more general observations of the former regarding "thoughts of mediation" ${ }^{68}$ According to the author of Material Phenomenology, any view that emphasises mediation turns out to be superficial. For it assumes, at the starting point, the possibility of remembering and recollecting, without problematising this capacity, while instead granting it the status of a kind of "preestablished harmony". ${ }^{69}$ This allows dragging memories from virtuality that, from a phenomenological standpoint, is identifiable with non-existence. However, it is precisely this possibility that denotes our original being, namely Potentiality, to use the terms of Henry himself: our original Archi-Body that conditions the persistence of all our possibilities, including those which are not at work at a certain point. ${ }^{70}$

While keeping in mind these important remarks on superficiality of the thought that prefers mediations, and recognising the relevance of the question of memory, we can skip directly to the late stage of Ricœur's philosophy. ${ }^{71}$

67 Ibidem, 349, n. 62; Michel Henry, Phénoménologie de la vie t. II: De la subjectivité (Paris: Presses Universitaires de France, 2003), 177-183.

${ }_{68}$ Henry, The Genealogy of Psychoanalysis, 325.

69 Ibidem, 326.

70 Ibidem, 326-327.

71 We cannot analyse in more detail the occurrences of the theme of life in Ricœur's main writings that belong to the narrative stage of his work - see e.g. Michaël Foessel, "The World of the Text and the World of Life: Two Contradictory Paradigms?", in: Hermeneutics and Phenomenology in Paul Ricœur: Between Text and Phenomenon, eds. Scott Davidson, MarcAntoine Vallée (Switzerland: Springer International Publishing, 2016), 75-86. Let us limit to recognise the importance of the theme, which is present in terms of an implicit ontology presupposed by the ontology of action - Frédéric Worms, "Paul Ricœur entre la vie et le mal, ou les coordonnées philosophiques du siècle”, in: Cahiers de L'Herne Paul Ricour, eds. Myriam Revault d'Allonnes, François Azouvi (Paris: Éditions de l'Herne, 2004), 322, and which reappears in the investigation focused on the "ground [the backdrop of being] at once actual and in potentiality" - Ricœur, Oneself as Another, 315, 317. 


\section{Life and the Fundamental: What about Immediacy?}

As far as life in the sense of something unconscious is concerned, the late book by Ricœur, Memory, History, Forgetting ${ }^{72}$ turns out to be more significant. In this work, while reflecting on the horizon of memory that constitutes oblivion, the thinker analyses its positive form related to the persistence of memory traces. ${ }^{73}$ In this context, he searches for the conditions of possibility of experiencing recognition, i.e. the acknowledgement of identity of a present representation of the thing being recognised (inasmuch as it unfailingly refers to that thing), despite of the otherness of this representation due to the fact that the thing is past. He concludes that there is at work a retrospective assumption or belief that something from the original impression has been preserved, although it has been lost for consciousness, albeit not definitively. Otherwise, memories could not return and be recognized as memories. In his reflection, the French philosopher follows Bergson, who, in the study Matter and Memory, by pure memories, means those which persist while remaining in a state of latency: inactive, virtual, schematic and unconscious traces. ${ }^{74}$ Such a virtual survival becomes object of a sort of belief, since it is out of reach of any form of perceiving. The survival of memory traces in this case appears as self-sustaining and expresses the fundamental accessibility of the virtually persisting past for the present.

To illustrate such a state of affairs, Bergson proposes a useful metaphor, namely that of the cone of time, the summit of which may be identified with the body acting in the present, while its base that contains inactive memories of the past becomes more voluminous proportionally to the increasing temporal distance from this pinpoint contact with the present. While the powerlessness of the surviving but inactive memories allows for referring

72 Paul Ricœur, Memory, History, Forgetting, transl. Kathleen Blamey, David Pellauer (Chicago: The University of Chicago Press, 2004).

${ }^{73}$ Ibidem, 427-443.

${ }^{74}$ It is noteworthy that Ricœur would agree, to some extent, with Henry as regards the insufficiency of neural approach: "a cortical trace does not survive in the sense of knowing itself as the trace of... - of the expired, past event; [...] if lived experience were not itself from the start self-surviving, and in this sense a psychical trace, it could never become so" - Ricœur, Memory, History, Forgetting, 439-440. 
them to the unconscious existence, the attention to life corresponds with the consciousness of the present moment of action. The experience of recognition plays the role of what is capable of overcoming the distance that separates the base of the cone of time from its summit. Thus, it engages together, within a kind of synergy regarding memory traces, action and representation, i.e. a material (neuronal) substratum and its semantic dimension that differs from Bergson's view. ${ }^{75}$ This discrepancy in opinion, which distinguishes Ricœur from the author of Matter and Memory, only reinforces the thesis of the self-survival of the memory traces: "This double affirmation suffices: first, that a cortical trace does not survive in the sense of knowing itself as the trace of... - of the expired, past event; next, that, if lived experience were not itself from the start self-surviving, and in this sense a psychical trace, it could never become so". ${ }^{76}$

According to the quoted thinker, all the above considerations may be coupled with Husserl's remarks on the consciousness of the flow (consciousness as a flow) that constitutes time, or more precisely, on the selfconstitution of time, inasmuch as they are applicable to the mere persistence of memory, beyond a phenomenological "visibility" of the flow. It is the case when they are taken up "in terms of the self-constitution of memory in passive syntheses, $[\ldots]$ under the sign of the $[\ldots]$ the cohesion of a life. $[\ldots]$ this is indeed a life and not a consciousness" ${ }^{77}$ Hence, the deep oblivion, in the sense of "the unperceived character of the perseverance of memories, their removal from the vigilance of consciousness", 78 is a sort of indicator of life. ${ }^{79}$

Moreover, the Freudian semantics of desire, while situated rather on a practical than cognitive plane, highlights the same vital ground as well. Undoubtedly, there exists a significant difference, or a kind of correction, in the approach to the unconscious by the founder of psychoanalysis, when

75 Ibidem, 438-439. More generally, Ricœur defeats the opposition between the lived action and representations twofold: by means of a more nuanced concept of representation (expressed in terms of different modes of presentation), and by the notion of action that includes a representational dimension.

${ }^{76}$ Ibidem, 439-440.

77 Ricœur, Critique and conviction, 93.

78 Ricœur, Memory, History, Forgetting, 440.

79 Ibidem, 506. 
compared with the account of Bergson. If it is true that both defend what cannot be forgotten, the latter defines it in terms of a powerlessness of the unconscious, while Freud, on the contrary, emphasises its tie with the drives of instinct, and consequently, its energy feature ${ }^{80}$ However, both views, namely the unconscious of the repressed drives and the unconscious of the inactive and latent memories, are not mutually exclusive. It is so, since the workingthrough by means of remembering, i.e. reaching the sources of libidinal forces, to use these psychoanalytical terms, couples with the work of mourning that consists in a separation from the lost object. ${ }^{81}$ As a result of such a double work (of remembering and mourning), the unconscious life turns out to be the foundation of memory, "the immemorial resource". ${ }^{2}$ As such, it may also become the very source of any renewal, any restoration that consists in unbinding the agent from his/her action..$^{83}$ And this is precisely the point of a new perplexity as to the nature of experience involved here.

On the one hand, Ricœur speaks of "the forgetting of foundations, of their original provisions, life force, creative force of history, [...] an origin always already there", ${ }^{84}$ of a kind of "fundamental forgetting" - and highlights that, to be somehow attained, it requires to "leave behind all narrative linearities; or, if we can still speak of narration, this would be a narrative that has broken with chronology". ${ }^{85}$ Perhaps, the linguistic expression at stake here is a performative one, like in the case of the aforementioned "hermeneutics of life"? On the other hand, and elsewhere, he notes that "memory is nothing apart from recounting". ${ }^{86}$ It seems that the "primordial equivocalness" or "double valence" 87 of forgetting (founding or destructive) remains its unsurpassable condition. ${ }^{88}$ Certainly, the philosopher underlines that with the "figures of deep, primordial forgetting, we reach a mythical ground of philosophizing" ${ }^{89}$ and

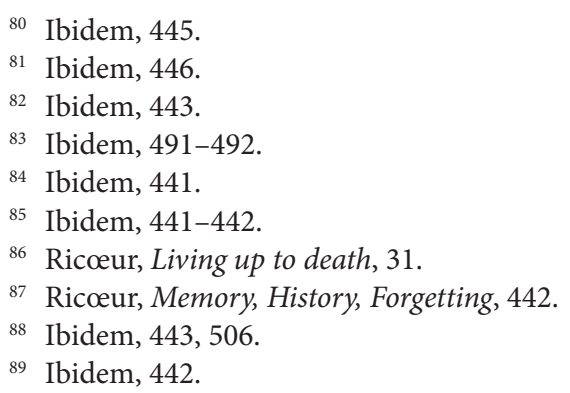


that the "fundamental ontology of power and act" implied here, "which can be traced in Leibniz, Spinoza, Schelling, Bergson, and Freud, reemerges [...] on the borders of moral philosophy, at the point where a philosophy of religion is grafted onto a deontological conception of morality". ${ }^{90}$ Yet is such a mythical inspiration the only possible reading in this case?

It seems that the author himself proposes an alternative under the sign of "the foregoing of representations" ${ }^{\text {"91 }}$ and living up to death. What is the origin of this last concept? In his polemic with Heidegger, the commented thinker detects in "the always imminent threat of dying [...] the joy of the spark of life". ${ }^{92}$ Ricœur's opposite reading divides into two stages. As to the first one, the author deals with it in Memory, History, Forgetting, where he formulates his key argument in favour of the pre-eminence of the theme of life in respect to death. The argument, in its negative part, presents Ricour's reluctance in regard to Heidegger's rush, which helps the latter to articulate "the ensuing slippages: being-a-whole, being outstanding as being in suspension, being-toward-the-end, being-toward-death". ${ }^{93}$ Furthermore, this strategy also sustains a number of backward definitions, namely "being-toward-death", as the own most possibility, becomes "being toward a possibility" (that closes a whole), what in its turn influences the open possibility of the potentiality-of-being. The positive part of the argument replaces Heideggerian "short-circuit" by a version of "the long detour", ${ }^{94}$ which, on the one hand, takes into consideration "the flesh of the living being [...] of desire that we are", "this carnal figure of care", ${ }^{95}$ and the teaching of the objective biological knowledge in the matter. Only at the end of the hard process of interiorising and appropriating it, may dying, which is characterised by "its radical heterogeneity in relation to our desire", ${ }^{96}$ be accepted, not by virtue of being a potentiality but as an ineluctable condition. On the other hand, the proposed reading

90 Ibidem, 491.

91 Olivier Abel, "Preface", in: Paul Ricœur, Living up to death, transl. David Pellauer (Chicago: The University of Chicago Press, 2009), XI.

92 Ricœur, Memory, History, Forgetting, 357.

93 Ibidem, 356.

94 Ibidem, 357.

95 Ibidem, 358.

96 Ibidem. 
includes the way that passes through the death of others: close and distant relations. ${ }^{97}$ The learning that thus becomes accessible concerns loss and mourning: communicational rupture as well as a sort of amputation of a part of oneself in the sense that self-identity partly consists of the lost relation. This in turn requires the work of mourning, i.e. an internal reconciliation with the loss. In this manner, by means of the loss of an object of attachment, one may realise his/her relation to life, which comes into light. ${ }^{98}$ Finally, the death of the distant other, being reflected on through the model of murder, insists on three features: violence, imminence, and equalisation which all threat the desire of life and, by the same token, expose it. ${ }^{99}$

After this brief overview of the conception of living up to death, one could ask after Worms where life "never ceases to emerge and at the same time, with a great deal of rigour and almost a certain modesty, to be covered up [:] Why [...] not to address it more directly?" 100 Ricœur indeed does it in Living up to death. In the pages of this work, the philosopher is more concerned with the experience of dying. When one reads these progressively less and less abstract and moving fragments, which otherwise concretise the path traced more theoretically in Memory, History, Forgetting, may appear striking the author's insistence on exorcising, on struggling with any kind of imaging of survival of the dying. ${ }^{101}$ Why is it so? According to the relevant observations of Y. Sugimura, the imagining regarding the dead functions so that blocks the experience of a loss by consolidating the attachment to the departed and a sort of negation of his/her death (and more generally, of the having to die). ${ }^{102}$ The only way that leads to the acceptance of both realities passes through the "bond of memory" 103 which in its turn requires the work of mourning. Even if memory usually does not do without images, a successful accomplishment

97 Ibidem, 359.

98 See Frédéric Worms, "Vivant jusqu’à la mort... et non pas pour la mort", Esprit 323, 3-4 (2006): 312.

99 Ricœur, Memory, History, Forgetting, 360-361.

100 Worms, "Vivant jusquà la mort..., 307 (my translation).

101 Ricour, Living up to death, 9-13.

102 Yasuhiko Sugimura, “'Demeurer vivant jusquà...' La question de la vie et de la mort et le 'religieux commun' chez le dernier Ricœur”, Études Ricœuriennes / Ricœur Studies 3, 2 (2012): 32 .

103 Ricœur, Living up to death, 4. And ibidem, 31: "memory heals the make-believe". 
of the work of mourning implies detachment from imaginary projections of one's self-identity after his/her own death as well, since our confrontation with others' decease is always concerned with our self-understanding. ${ }^{104}$ It becomes clear that this mourning and detachment represent quite a difficult task to effectuate. Therefore, it seems justifiable to ask what can play the role of a motivational factor needed to undertake it. ${ }^{105}$

It is precisely in connexion with such a reflective background that Ricœur evokes the emergence of the Fundamental, of the Essential. ${ }^{106}$ Mostly, this kind of reference appears in the middle of the lived experience of accompanying the dying, but not exclusively. ${ }^{107}$ What does the notion of the Essential (Fundamental) denote? It is a matter of "the deepest resources of life", of "the religious $[\ldots]$ which is common to every religion and [...], at the threshold ofdeath, transgresses the consubstantiallimitations of confessing and confessed religions". ${ }^{108}$ This "religious in common" may be compared to "a fundamental language that exists only in natural, historically limited languages", although these "articulate [it] only on the condition of filtering, and in this sense limiting" 109 its amplitude, depth, and density. In one particular situation, namely "in the face of death", it fractures "the limitations of the confessionally religious" and "gets equated with the Essential". ${ }^{110}$ Indeed, we have to do here with an exception: "the grace of a certain dying", in which case we probably meet "the only situation where one can speak of religious experience", ${ }^{111}$ and this despite of the author's wariness with regard to what is immediate, intuitive, or mystical. Moreover, "the movement of transcendence immanent transcendence [...] innermost to the Essential", ${ }^{112}$ comes to light which forms part of this experience. The immanent aspect of what is dealt with in this point seems probably to refer to "the experience that life has

\footnotetext{
104 Ibidem, 41-48.

105 Sugimura, “'Demeurer vivant jusqu’a...”, 32.

106 Ricœur, Living up to death, 14-22, 42-43, 51; Critique and conviction, 158, 160-161.

107 Ricour, Living up to death, 42-43, 51; Critique and conviction, 158, 182.

108 Ricœur, Living up to death, 14.

109 Ibidem, 15.

110 Ibidem.

111 Ibidem, 16.

112 Ibidem, 17-18.
} 
of itself", ${ }^{113}$ which resources are mobilising in "the crucial region of the soul where absolute Evil is opposed to fraternity". ${ }^{114}$ The transcendent aspect in its turn points out to the two-dimensional predominance of life over death: once transferred by means of memory, it is preserved horizontally in the others, and vertically in "memory of God". ${ }^{115}$ Thus, the special temporality of the Fundamental is revealed, and backwardly, the importance of the work of mourning (and detachment from oneself) in favour of the good use of memory. The appropriate use of the latter consists in activating the deep resources of life, and by the same token, in uttering "a word of hope, torn from what is unspoken". ${ }^{16}$ Then the permanence of life apparently turns out to be not only what protects from insanity the bond of memory, ${ }^{117}$ but also what safeguards hope and fraternity from overwhelming insistence of evil. ${ }^{118}$

In the final analysis, what results from all these considerations for our axial problem of the rivalry between mediation and immediacy in Ricœurian thought? It seems that we are justified in reformulating this problem in terms of two opposing figures of memory: memory as a figure of care (which implies mediation), and a type of carefree memory, which corresponds to the transfer to the other of one's care of life (closer to an immediacy). ${ }^{119}$ While making reference to the latter, we nonetheless do not tacitly concede in favour of an irresponsible carelessness, since such an opportunity (of this reference) only emerges at the end of a long and difficult work of mourning and personal detachment. ${ }^{120}$ As to this point, I totally agree with the view of Sugimura that this double work successfully dissuades the philosopher from an excessive concession in respect to the enchantment stemming not only from the imaginary but also from the religious immediacy. ${ }^{121}$ Even though he appears to be using religious language discussing the uncontrollable areas traced by the expression "living up to...", especially regarding the concepts of life

\footnotetext{
113 Ibidem, 32.

114 Ibidem, 38.

115 Ricœur, Critique and conviction, 161; Living up to death, 41-55.

116 Ricœur, Living up to death, 39.

117 Sugimura, “'Demeurer vivant jusqu’à...”, 32-33.

118 Ricœur, Living up to death, 38-40.

119 Ricœur, Memory, History, Forgetting, 505.

120 Ibidem, 495-505; Ricœur, Living up to death, 7-55 (passim).

121 Sugimura, “Demeurer vivant jusquà...”, 33-34.
} 
resources and detachment - which may be seen as an act of philosophical humiliation - Ricœur simply articulates his omnipresent philosophical conviction. The latter contains the declaration according to which the "reference of the linguistic order back to the structure of experience (which comes to language in the assertion) constitutes [...] the most important phenomenological presupposition of hermeneutics". 122 In other words, life inasmuch as it identifies with a motivational source and the whole of resources of renewal, "binds us together as capable human beings", and consequently, as "components and expressions of Life". ${ }^{123}$ Thus, on the one hand, it reveals itself in its nature of what encompasses all our experience. As such, it evokes the One - the origin of ontological hope - Ricœur spoke of many years before. ${ }^{124}$ Yet, on the other hand, the equivocalness of the two aforementioned figures of memory remains basically undecidable, ${ }^{125}$ meaning that there is "no final assessment" 126 as to if the immediacy of life prevails the mediation of narratives. But this is not our conclusive statement.

The problem becomes more complex when one examines some passages of Living up to death more closely. ${ }^{127}$ One may wonder if the reflections that may be found there are not in fact influenced by the Kantian-like hope of a final happiness, a hope driven by the dynamism of life. The question seems to be legitimate since an unsurpassable tension penetrates the discourse of these interesting and dramatic pages. On the one hand, what is evident is a polarity between the attestation of one's self-identity, which serves to maintain ethical responsibility and justice, and a detachment accompanied by a renouncement of this identity in favour of transmitting one's own care to the other(s). On the other hand, even the former pole of the alternative seems to be disjunctive,

122 Ricœur, Hermeneutics and the Human Sciences, 78.

123 James Carter, Ricœur on Moral Religion: A Hermeneutics of Ethical Life (New York: Oxford University Press, 2014), 6. It is noteworthy that the author proposes a precious distinction concerning Ricœurian account of life: "life', with a lower case, which designates lived human experience, and 'Life', with an upper case, which designates the wider whole of which we are all a part, and which encompasses lived human experience" - ibidem.

124 Paul Ricœur, History and Truth, transl. Charles A. Kelbley (Evanston: Northwestern University Press, 1965), 53-56.

125 Ricœur, Memory, History, Forgetting, 443, 506.

126 Ibidem, 443.

127 Ricour, Living up to death, 48-49. 
it is not exempt from an implicit effectivity of the fundamental, as long as both the identity of the agent and the ethics of responsibility require a kind of balance between preservation of the having-been and expectation. The latter, namely expectation, turns out to be rooted "in the desire for life under the sign of perfect detachment". ${ }^{128}$ Perhaps, it is useless to recall that the balance in question is a distinctive trait of Ricœur's hermeneutical philosophy of action. ${ }^{129}$ And, if so, life appears as the factor which structures the author's philosophical discourse to a significant extent. ${ }^{130}$

Such a state of affairs may be unsurprising, given its accordance with the thinker's ontology of disproportion. ${ }^{131}$ If applied to the "groundless ground" (in Schelling's terms) that identifies with "the very source of life that all receive, but that no one can encompass", ${ }^{132}$ comes to light the particular position of life in Ricœur. The acknowledgement of the finiteness of the human capacity to receive while what is received remains infinite, seems to pertinently summarise this position. This allows for its comparison with that of the inexhaustible source of meaning, ${ }^{133}$ or elsewhere with that of God as an ultimate referent of all the discourses that name it. ${ }^{134}$ This is why, just after the publication of Time and Narrative, some critics were not totally wrong when they reproached Ricœur for the fact that the coherence of his discourse remains incomplete due to the presupposition of the God of the Bible, even if he terms it differently. ${ }^{135}$ Perhaps, all things considered, this problematic status of the analysed thought, which makes it dependent

128 Ibidem, 48.

129 See e.g. Ricœur, Time and Narrative, vol. 3, 230-235.

130 Paul Ricœur, "Hope and the Structure of Philosophical Systems", Proceedings of the American Catholic Philosophical Association 44 (1970): 55-69, DOI: https://doi.org/10.5840/ acpaproc1970449.

131 Gregor, Ricœur's Hermeneutics of Religion, ch. 9.

132 Paul Ricœur, "Religious Belief: The Difficult Path of the Religious", in: A Passion for the Possible: Thinking with Paul Ricœur, eds. Brian Treanor, Henry Isaac Venema (New York: Fordham University Press, 2010), 35.

133 Ricœur, Critique and conviction, 150, 170.

134 See e.g. Paul Ricœur, Figuring the Sacred: Religion, Narrative, and Imagination, transl. David Pellauer (Minneapolis: Fortress Press, 1995), 45-46.

135 Christian Bouchindhomme, "Limites et présupposés de l'herméneutique de Paul Ricœur", in: Temps et récit de Paul Ricœur en débat, eds. Christian Bouchindhomme, Rainer Rochlitz (Paris: Éditions du Cerf, 1990), 179-182. 
at least on the attractive influence of hope, on the "Yes" option, ${ }^{136}$ reflects only "the sort of [allegedly] controlled schizophrenia"137 between critical thinking and convictions, so that the "rule of thought" was finally overtaken by the apparently uncontrollable "rule of life" 138 ... Would Henry be right when speaking of the superficiality of thinking that relies on mediations, and uncovering the "preestablished harmony" of meaningful life, harmony uncritically dragged from phenomenological vacuity?

\section{Concluding Observations}

To my knowledge, there is a different way of coping with the above difficulty. It recognises its affinity with Rasmussen's proposal of detecting an eidetic moment preserved within the entire work of Ricœur. ${ }^{139}$ As this commentator underlines, this persisting concern consists in focusing on subjectivity: "Ricœur's uniqueness was that he would always retain a kind of Husserlian preoccupation with subjectivity, immediacy, time, and temporality, even though he had made the move to language", ${ }^{140}$ and this to the point that "no one else has been able to do that with his freshness and originality". ${ }^{141}$ For my part, while agreeing with this statement, I dare to suggest that a backward and careful reading of Ricœur's legacy would be able to establish a special role for attention. Let us stress it at the outset: in no way does this mean the restoration of human consciousness to its central position and self-transparency. Therefore, there is no foundational and metaphysical-like claim in this

\footnotetext{
136 Ricœur, Freedom and Nature, 466-480.

137 Ricour, Critique and conviction, 2.

138 Ibidem. As to a similar view, see Henry Isaac Venema, "The Source of Ricœur's Double Allegiance", in: A Passion for the Possible: Thinking with Paul Ricour, eds. Brian Treanor, Henry Isaac Venema (New York: Fordham University Press, 2010), 62-76.

139 David Rasmussen, "Preserving the Eidetic Moment: Reflections on the Work of Paul Ricœur", in: A Passion for the Possible: Thinking with Paul Ricour, eds. Brian Treanor, Henry Isaac Venema (New York: Fordham University Press, 2010), 190-196.

140 Ibidem, 192.

141 Ibidem, 196.
} 
account, but rather a clarification and subjective concretisation of the main phenomenological presupposition of hermeneutics.

Why attention? First of all, because it seems to be the only strictly phenomenological moment of which the author himself speaks as follows: "the generosity of the thrust. I suspend the parentheses which suspended the act". ${ }^{142}$ Thus attention constitutes a privileged sphere where meaning may appear as meaning. In this respect, it opens the very dimension of phenomenalisation. The functioning of attention entails an interrupting of the sort of "hyper-reflection" that indefinitely closes "a circle with myself in the sterility of an endless return to myself" 143 and consists in activating the "power for contradictories which lies at the very roots of motivation". ${ }^{144}$ It combines "the highest activity" and the "greatest receptivity" 145 brought about by the former, as well as determination of the act and indetermination of the power, ${ }^{146}$ according to "that temporal shift of vision which turns towards or turns away from". ${ }^{147}$ Attention turns out to not only be susceptible of rational motives, but also of emotional ones; as well of formal values as of material ones. ${ }^{148}$ It becomes "not anticipation but wonder", ${ }^{149}$ "that silence in which all voices echo" and "which creates time, wins time, so that all these voices speak distinctly". ${ }^{150}$ Nevertheless, attention retains this movement of observation that displaces itself and thus, by means of the imagination, changes the mode of the appearance of the respective aspects of objects. ${ }^{151}$ This is why Henry is largely correct when criticising, alongside the metaphysics of representation, the perceptive model of appearing in terms of its exclusiveness. His notes might probably serve to outline the manner in which attention acts, more independently from perception. Yet, while doing so, he probably goes too far since he overlooks his own implicit hermeneutics, which even if deals with a kind of per-

\footnotetext{
142 Ricœur, Freedom and Nature, 189.

143 Ibidem.

144 Ibidem, 188.

145 Ibidem, 155.

146 Ibidem, 185-187.

147 Ibidem, 155-156.

148 Ibidem, 157-160.

149 Ibidem, 155.

150 Ibidem, 163.

151 Ibidem, 154.
} 
formative language of life, has to be operative at least in order to assess the correctness of a description and for polemic purposes. Attention seems to be placed somehow in between: it is neither bonded exclusively to objective intentionality nor to the pure and radically imperceptible auto-affectivity. Notwithstanding, it conceivably represents the culmination point of any reachable proximity between the philosophy of mediation and that of immediacy.

\section{Bibliography}

Abel Olivier. 2009. "Preface". In: Paul Ricœur, Living up to death, transl. David Pellauer, VII-XXII. Chicago: The University of Chicago Press.

Bégout Bruce. 2006. "L'héritier hérétique. Ricœur et la phénoménologie". Esprit 323, 3-4: 195-209.

Bouchindhomme Christian. 1990. "Limites et présupposés de l'herméneutique de Paul Ricœur". In: Temps et récit de Paul Ricour en débat, eds. Christian Bouchindhomme, Rainer Rochlitz, 163-183. Paris: Éditions du Cerf.

Carter James. 2014. Ricœur on Moral Religion: A Hermeneutics of Ethical Life. New York: Oxford University Press.

Castonguay Simon. 2016. "La Généalogie de la psychanalyse de Michel Henry: Des limites du paradigme de la représentation". In: Paul Ricour et Michel Henry. Entre héritages et destinées phénoménologiques, eds. Jean-Sébastien Hardy, Jean Leclercq, Cyndie Sautereau, 133-149. Louvain-la-Neuve: Presses Universitaires de Louvain.

Davidson Scott. 2016. "La phénoménologie de la vie: entre Henry et Ricœur", transl. Daniel Gillis. In: Paul Ricour et Michel Henry. Entre héritages et destinées phénoménologiques, eds. Jean-Sébastien Hardy, Jean Leclercq, Cyndie Sautereau, 33-48. Louvain-la-Neuve: Presses Universitaires de Louvain.

Davidson Scott. 2018. "The Phenomenon of Life and Its Pathos". In: Scott Davidson, A Companion to Ricoeur's "Freedom and Nature", 157-172. Lanham, MD: Lexington Books.

Del Mastro Cesare. 2016. "De la co-référence à la co-impression: La phénoménologie henryenne du langage au prisme de Temps et récit". In: Paul Ricour et Michel Henry. Entre héritages et destinées phénoménologiques, eds. Jean-Sébastien Hardy, Jean Leclercq, Cyndie Sautereau, 73-97. Louvain-la-Neuve: Presses Universitaires de Louvain.

Dosse François. 2008. Paul Ricœur. Les sens d’une vie (1913-2005). Paris: La Découverte. 
Foessel Michaël. 2016. "The World of the Text and the World of Life: Two Contradictory Paradigms?". In: Hermeneutics and Phenomenology in Paul Ricour: Between Text and Phenomenon, eds. Scott Davidson, Marc-Antoine Vallée, 75-86. Switzerland: Springer International Publishing.

Formisano Roberto. 2016. "Vie et représentation: Henry et Ricœur sur le problème de la praxis". In: Paul Ricour et Michel Henry. Entre héritages et destinées phénoménologiques, eds. Jean-Sébastien Hardy, Jean Leclercq, Cyndie Sautereau, 195-205. Louvain-la-Neuve: Presses Universitaires de Louvain.

Gregor Brian. 2019. Riccur's Hermeneutics of Religion: Rebirth of the Capable Self. Lanham: Lexington Books.

Hardy Jean-Sébastien, Jean Leclercq. 2016. "Introduction: Paul Ricœur et Michel Henry, entre héritages et destinées". In: Paul Ricour et Michel Henry. Entre héritages et destinées phénoménologiques, eds. Jean-Sébastien Hardy, Jean Leclercq, Cyndie Sautereau, 3-14. Louvain-la-Neuve: Presses Universitaires de Louvain.

Henry Michel. 1993. The Genealogy of Psychoanalysis, transl. Douglas Brick. Stanford, California: Stanford University Press.

Henry Michel. 2003. Phénoménologie de la vie t. II: De la subjectivité. Paris: Presses Universitaires de France.

Moyaert Marianne. 2014. In Response to the Religious Other: Ricour and the Fragility of Interreligious Encounters. Lanham: Lexington Books.

Proença Nuno Miguel. 2016. "La signification de l'inconscient: Psychanalyse, herméneutique et phénoménologie de la vie". In: Paul Ricœur et Michel Henry. Entre héritages et destinées phénoménologiques, eds. Jean-Sébastien Hardy, Jean Leclercq, Cyndie Sautereau, 111-131. Louvain-la-Neuve: Presses Universitaires de Louvain.

Rasmussen David. 2010. "Preserving the Eidetic Moment: Reflections on the Work of Paul Ricœur". In: A Passion for the Possible: Thinking with Paul Ricour, eds. Brian Treanor, Henry Isaac Venema, 190-196. New York: Fordham University Press.

Ricœur Paul. 1965. History and Truth, transl. Charles A. Kelbley. Evanston: Northwestern University Press.

Ricœur Paul. 1966. Freedom and Nature: The Voluntary and the Involuntary, transl. Erazim V. Kohák. Evanston: Northwestern University Press.

Ricœur Paul. 1970. "Hope and the Structure of Philosophical Systems". Proceedings of the American Catholic Philosophical Association 44: 55-69, DOI: https://doi. org/10.5840/acpaproc1970449.

Ricœur Paul. 1970. Freud and Philosophy: An Essay on Interpretation, transl. Denis Savage. New Haven and London: Yale University Press.

Ricœur Paul. 1984. Time and Narrative. Vol. 1, transl. Kathleen McLaughlin, David Pellauer. Chicago: The University of Chicago Press. 
Ricœur Paul. 1990. Time and Narrative. Vol. 3, transl. Kathleen Blamey, David Pellauer. Chicago: The University of Chicago Press.

Ricœur Paul. 1992. Oneself as Another, transl. Kathleen Blamey. Chicago: The University of Chicago Press.

Ricœur Paul. 1995. Figuring the Sacred: Religion, Narrative, and Imagination, transl. David Pellauer. Minneapolis: Fortress Press.

Ricœur Paul. 1998. Critique and conviction: conversations with François Azouvi and Marc de Launay, transl. Kathleen Blamey. New York: Columbia University Press.

Ricœur Paul. 2004. Memory, History, Forgetting, transl. Kathleen Blamey, David Pellauer. Chicago: The University of Chicago Press.

Ricœur Paul. 2009. Living up to death, transl. David Pellauer. Chicago: The University of Chicago Press.

Ricœur Paul. 2010. "Religious Belief: The Difficult Path of the Religious". In: A Passion for the Possible: Thinking with Paul Ricour, eds. Brian Treanor, Henry Isaac Venema, 27-40. New York: Fordham University Press.

Ricœur Paul. 2016. Hermeneutics and the Human Sciences: Essays on Language, Action and Interpretation, transl. John Brookshire Thompson. New York: Cambridge University Press.

Serban Claudia. 2016. "De l'hylétique à l'herméneutique: Henry et Ricœur face à Husserl". In: Paul Ricoeur et Michel Henry. Entre héritages et destinées phénoménologiques, eds. Jean-Sébastien Hardy, Jean Leclercq, Cyndie Sautereau, 17-32. Louvain-la-Neuve: Presses Universitaires de Louvain.

Sugimura Yasuhiko. 2012. "Demeurer vivant jusquà...' La question de la vie et de la mort et le 'religieux commun' chez le dernier Ricœur". Études Ricœuriennes / Ricour Studies 3, 2: 26-37.

Venema Henry Isaac. 2010. “The Source of Ricœur's Double Allegiance”. In: A Passion for the Possible: Thinking with Paul Ricour, eds. Brian Treanor, Henry Isaac Venema, 62-76. New York: Fordham University Press.

Worms Frédéric. 2004. "Paul Ricœur entre la vie et le mal, ou les coordonnées philosophiques du siècle”. In: Cahiers de L'Herne Paul Ricœur, eds. Myriam Revault d'Allonnes, François Azouvi, 315-325. Paris: Éditions de l'Herne.

Worms Frédéric. 2006. "Vivant jusquà la mort... et non pas pour la mort". Esprit 323, 3-4: 304-315.

\begin{abstract}
The paper deals with the problem of life within the thought of Paul Ricœur. The existing literature in the matter, as well as the limited purpose that orients the endeavour below, requires a selection of the aspects to be investigated. The research question that constitutes the guiding thread of the analysis focuses on the opposition
\end{abstract}


between mediation and immediacy, inasmuch as it appears in the examined philosophy. Having accounted for the present state of the question, life is approached in a twofold manner: in the guise of desire and in the figure of the Fundamental. An essential critique of Henry, addressed with regard to the former aspect of the problem, turns out to be applicable as to the latter as well. All this helps to discern an eidetic moment that persists throughout Ricœur's legacy without being constantly highlighted.

Keywords: life, desire, the Fundamental (the Essential), mediation, immediacy, attention, Ricœur 